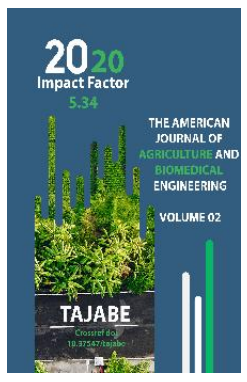

Copyright: Original content from this work may be used under the terms of the creative commons attributes 4.0 licence.

\section{Current Pests Eriophyes Vitis Nal Damage And Combined Methods}

\author{
Sardor Ubaydullaev \\ Tashkent State Agrarian University, Uzbekistan \\ Rano Muminova \\ Tashkent State Agrarian University, Uzbekistan
}

\title{
ABSTRACT
}

The article provides information about injuriousness of grape mites and preparations insectoaricides as abalon, $1,8 \%$, Killer, $5 \%$ and Microfiol $80 \%$, which were used against this vermin. The shown efficieng of such preparation varies from 90,0 to $93,9 \%$ respectively.

\section{KEYWORDS}

Against, Abalon, Pilarmectin, acaricides, biologically.

\section{INTRODUCTION}

Viticulture is one of the main branches of agriculture in the country. The vine and its products occupy a separate place among other perennials. The natural climatic conditions of the republic allow grapes to ripen at different times. In recent years, several species of pests have significantly affected the yield of grapes. The most common of these pests are vine mites.
Eriophyes vitis Nal belongs to the group of four-limbed canals - Eriophyoidae Reibev of the main family Eriophyidae and is widespread in almost all regions of Uzbekistan [3].

In particular, strong damage is observed to wine grape varieties. Currents damaged by the current channel lag behind in development. In particular, productivity decreases sharply and quality indicators deteriorate [5]. 


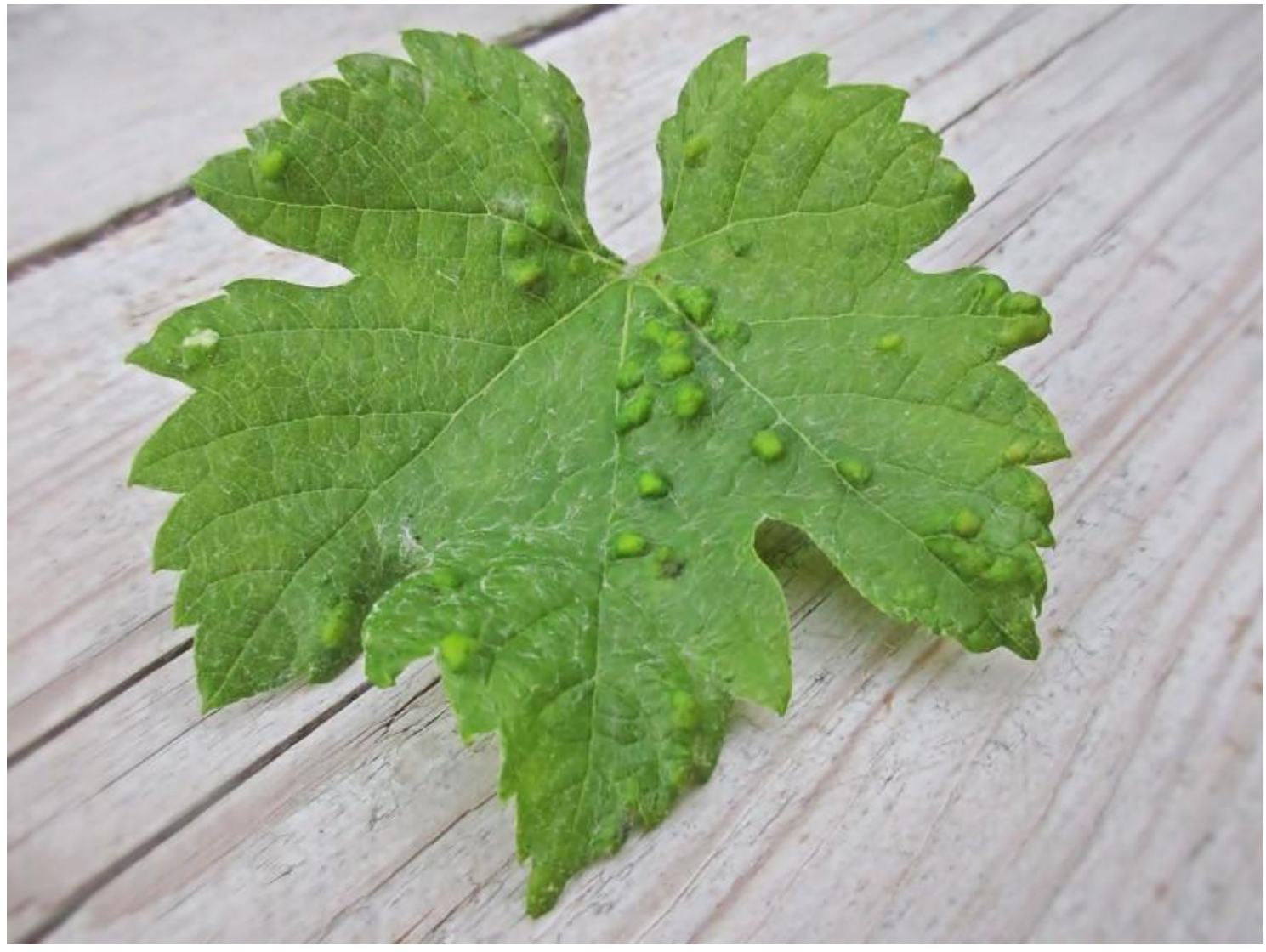

current pest eriophyes vitis nal damage

The vine overwinters under the bark and around the buds. In the spring (late April, May) it wakes up, sprouts new leaves and begins to damage it. Sh.Esonboev and b. [4] observed that primary (productive) buds died and secondary and tertiary (infertile) buds developed as a result of the presence of a special biological type of vine and that it damaged not only the leaves but also the buds. An unattended vine is more likely to damage weeds that have been overgrown with weeds and have not risen to the vine [4].

According to the observations of 2018-2019, as a result of uneven swelling (gall) on the leaf surface due to damage to the vine, the developmental stages of the vine took place under the gall coverings (erineum) [5].

They are only resistant to chemicals when migrating to other leaves of the vine. It is important to use contact and systemic (systemic) drugs against these pests [1].

Measures to combat the current in the country have not been sufficiently studied. We should therefore aim to study the effects of promising preparations against this pest. Against this pest Abalon, 1.8\% k.e., Killer, 5\% k.e., Pilarmectin (standard) 1.8\% em.k. drugs were tested and their biological efficacy was determined [5]. 

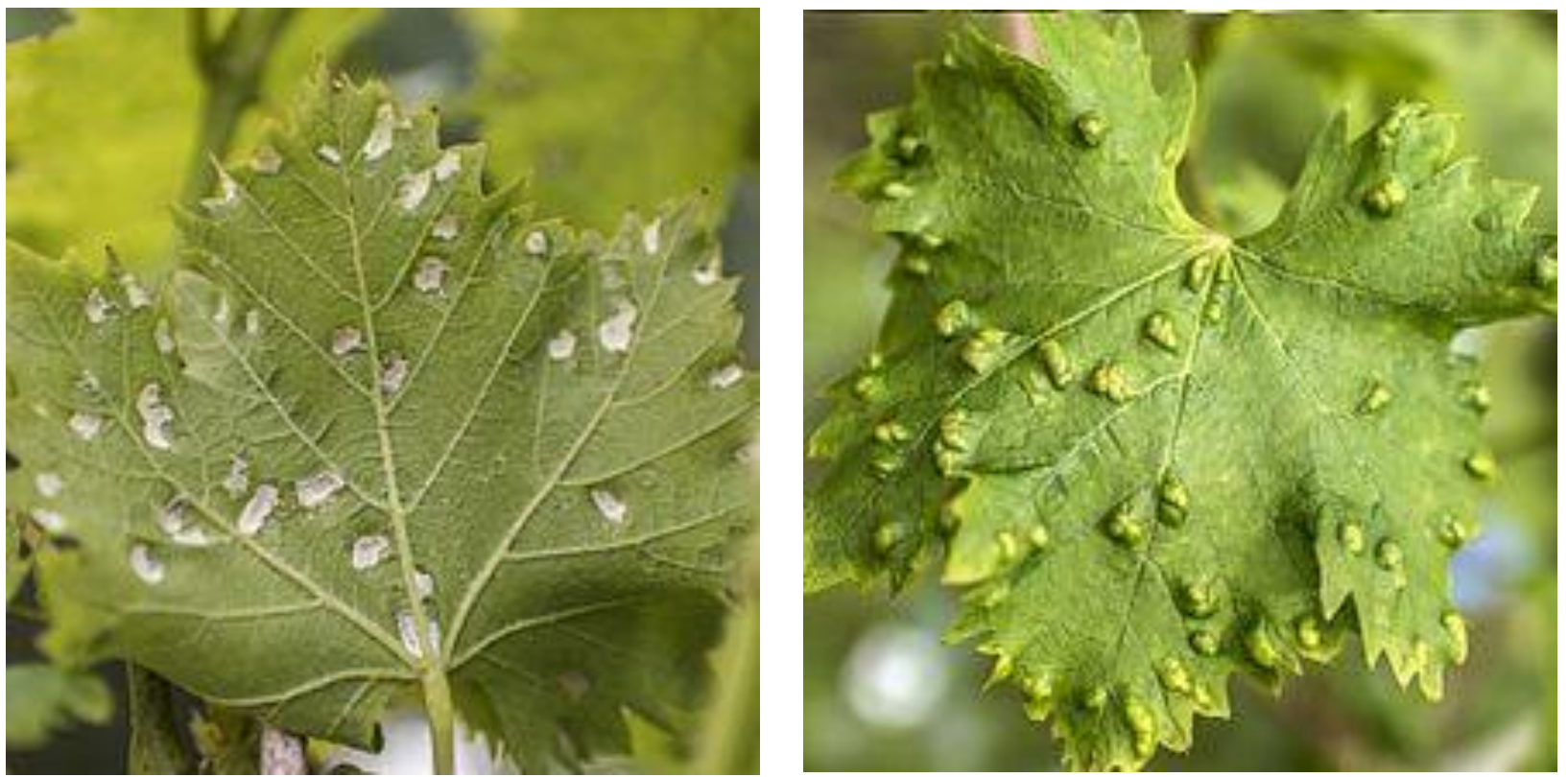

damaged vine leaves

\section{RESEARCH RESULTS}

The experiments were carried out on the basis of "Methodological guidelines for testing insecticides, acaricides, biologically active substances and fungicides" published under the editorship of Sh.T.Khojaev [2]. In this case, 10 samples were taken from the middle part of the 3 repetitions in each variant to calculate the amount of mite in the current. In each sample, 3 damaged rods were seen and the average amount of cane corresponding to 1 rod was determined. Observations before and after drug injection 3; 7; Held on the 14th and 21st. The working fluid was obtained at the rate of $1000 \mathrm{l}$. The biological effectiveness of drugs was calculated on the basis of the formula of Abbott (1925).

The experiments were carried out in the experimental field of BUva VITI Kibray "Sharob" IEC named after academician M.Mirzaev. 


\section{Table 1}

Biological efficacy of drugs used against Eriophyes vitis (2018-2019).

\begin{tabular}{|c|c|c|c|c|c|c|c|}
\hline \multirow[b]{2}{*}{ № } & \multirow[b]{2}{*}{ Options } & \multirow{2}{*}{$\begin{array}{c}\text { Drug } \\
\text { consumption } \\
\text { Concentration\% }\end{array}$} & \multirow{2}{*}{$\begin{array}{c}\text { The average } \\
\text { number of pests } \\
\text { on } 1 \text { branch before } \\
\text { processing }\end{array}$} & \multicolumn{4}{|c|}{ Biological efficiency } \\
\hline & & & & $\begin{array}{c}3 \\
\text { days }\end{array}$ & $\begin{array}{c}7 \\
\text { days }\end{array}$ & $\begin{array}{c}14 \\
\text { days }\end{array}$ & $\begin{array}{c}21 \\
\text { days }\end{array}$ \\
\hline 1 & Kilder, 5\% k.e. & 0,04 & 42,3 & 76,2 & 80,0 & 86,9 & 91,4 \\
\hline 2 & Abalon, $1.8 \%$ k.e. & 0,03 & 46,5 & 77,6 & 84,3 & 90,2 & 94,5 \\
\hline 3 & $\begin{array}{c}\text { Pilarmectin, } 1.8 \% \\
\text { e.k. }\end{array}$ & 0,025 & 45,1 & 75,7 & 82,4 & 90,0 & 93,5 \\
\hline 4 & \multicolumn{2}{|c|}{ Control (unprocessed) } & 45,7 & - & - & - & - \\
\hline
\end{tabular}

\section{CONCLUSIONS, SUGGESTIONS AND}

\section{RECOMMENDATIONS}

The table shows that Abalon is $1.8 \%$ k.e. (0.03\%) The drug was found to have a biological efficacy of $94.5 \%$ on 21 days against vine. Killer $5 \%$ k.e. When applied (0.04\%), the biological efficacy was $91.4 \%$ on day 21 . (Pilarmectin $1.8 \%$ em.c. 0.025 ) and up to $93.5 \%$ (21-day) pest mortality was observed.

One of the main measures to combat pests and diseases of the vine is the correct designation of agro-technical measures. These include weeding, timely weeding, loosening row spacing, removing cut branches from vineyards in autumn, treatment with 3\% Bordeaux liquid before burial, and giving 2000-2500 m3 of jasmine water in winter.

Hence, Abalon against the vine, $1.8 \%$ k.e. (0.03\%), Killer, $5 \%$ k.e. (0.4\%) and Pilarmectin, $1.8 \%$ e.k. (0.025\%) It is advisable to use insect acaricides in the recommended doses.

\section{REFERENCES}

1.

2.

3.

$4 \cdot$
K.Sh.Mamatov, A.A.Hakimov, A.N.Malikov, D.Nasimova "Effectiveness of promising chemical preparations against vine in wine grapes" // Journal of plant protection and quarantine 2015. №2. 15 b.

Sh.T.Khojaev, "Guidelines for testing insecticides, acaricides, biologically active substances and fungicides." Tashkent. KOHI-NUR. 2004, 104 p.

Sh.T.Khojaev "Fundamentals of entomology, protection of agricultural crops and agrotoxicology" // Tashkent 2015. $63 \mathrm{~b}$.

Sh.Esonbaev O.Mahmudov, K.Sh.Mamatov "Determining the terms of convenient struggle 


\section{against the vine of vineyards" //}

Agro ilm - 2014. №2. 50-51 b.

5. A.Malikov, D.Nasimova "Damage of vine to grapes and methods of its control" // Journal. Plant protection and quarantine - 2016. №3. 23-24 b.

6. B.E.Murodov, J.N.Yakhyoyev Quarantine pests of internal quarantine of the Republic of Uzbekistan // Education and science in Russia and abroad. 2017. - No. 3 (32). -FROM. 32-36. 